\title{
Viyana Müzeler Avlusu: Serbest Zaman Bedenleri ve Kamusal Mekân
}

\section{Özet}

Bu yazı Avrupa'nın en canlı kültürel kamusal mekânlarından biri olarak kabul edilen tarihi ve çağdaş kentsel dokuların buluștuğu Viyana Müzeler Avlusu'na odaklanmaktadır. Yazıda. Henri Lefebvre'in felsefi bağlamda irdelediği mekân ve beden iç içeliği kuramsal bir çerçeve olarak benimsenmekte ve odaklanılan Viyana Müzeler Avlusu bu önermenin doğruluğunu anlamaya yönelik bir zemin ve odaklanılan Viyana Müzeler Avlusu bu onermenin doğruluğunu anlamaya yönelik bir zemin
oluşturmaktadır. Kamusal mekân ve kamusal beden iç içeliği hem avlunun tarihsel ve tektonik çok oluşturmaktadır. Kamusal mekân ve kamusal beden iç içeliği hem avlunun tarihsel ve tektonik çok
katmanlılığı hem de kentsel kültürün önemli bileşenlerinden olan serbest zaman kavramı bağlamındo irdelenmektedir. Avlunun mekânsal pratiği sadece onu tarifleyen müzelerin ve çeşitli kültürel etkinlikleri barındıran tarihi yapıların mimari kurgusu üzerinden değil, çok özel kentsel mobilyalarının katkısı da vurgulanarak tartıșılmaktadır.

Anahtar Kelimler: Kamusal Mekân, Mekânsal Pratik, Beden, Kentsel Kültür, Müze

VIENNA MUSEUMS COURTYARD: LEISURE TIME BODIES AND PUBLIC SPACE

\section{Abstract}

This article focuses on the Vienna Museums Courtyard, one of the most lively cultural public spaces of Europe where the historical and contemporary urban textures coexist. Within the article. Henri Lefebvre's philosophical approach to the reciprocal inherence of space and body is employed as a theoretical framework and Vienna Museums Courtyard constitutes a ground to verify this suggestion. theoretical framework and Vienna Museums Courtyard constitutes a ground to verify this suggestion. The intertwined nature of public space and public/societal body is examined regarding both contexts culture. The spatial practice of the courtyard is discussed not merely through the architectural prestructuring of the museums and historical buildings that define the courtyard but also through an emphasis upon its very unique urban furniture.

Keywords: Public Space, Spatial Practice, Body, Urban Culture, Museum 
Viyana Müzeler Avlusu: Serbest Zaman Bedenleri ve Kamusal Mekân

"her canlı beden bir mekândır..."

Henri Lefebvre (1974/20/4: 188)

\section{Tektonik ve Beden / İçeren ve İçerilen}

Henri Lefebvre Mekânın Üretimi başıklı eserinde mekânın, salt fiziksel nitelikleri merkezileştiren bir anlayışla kavranmasındaki eksikliği sorgularken, toplumsal mekânı anlamak için bedene gönderme yapılabileceğinden söz eder (1974/2014: 69). Gerçekten de bir kentin kamusal mekânları, açık alanları ve meydanları kentlinin mekânsal pratikleri ile, yani zihinsel ve toplumsal beden ile buluştuğu nisbette o kent hakkında güçlü bildirimler yapar. Mimari bağlamda bu bildirimler büyük ölçüde, mekânı tektonik olarak tarifleyen yapı veya yapı gruplarıyla ilişkilendirilir. Zihinselliği ve toplumsallığı birlikte barındıran "kamusal bedenin" buradaki örtük tanımı (belki de yan rolü), sıklıkla, mekâna sonradan katılan, mekânı işgal eden ve mekânda içerilendir. Bu yaklaşımda mekân bir içeren konumundadır. Mimarlık disiplininin önceliğinin mekânın tektoniği olduğu varsayımı, bu aslında oldukça sorunlu yaklașıma sağlam bir zemin hazırlamaktadır; ama aynı zamanda, tersi bir yaklaşımı da akıllara düşürmektedir. "Kamusal beden" bir içeren olarak mekânsallık üretebilir mi? Bu yazı ile hedeflenen, bunların her iki yönde de içeren ve içerilen simetrisinde olmadığı, aksine, birbirinin içinde olduğu önermesine somut bir kentsel mekân üzerinden dikkat çekmektir.

Yazının odaklandığı Viyana Müzeler Avlusu, Lefebvre'in Mekânın Üretimi'nin 'Mekânsal Arkitektonik' bölümünde felsefi bağlamda irdelediği mekân(sallık) ve beden(sellik) ikililiğinden yola çıkılarak yapılan bu iç içelik önermesinin doğruluğunu anlamaya yönelik bir zemin oluşturmaktadır (1974/2014: 187-240). Burada bir parantez açmak gerekirse, kent düşünürü Lefebvre, zaman aşımına uğramayan bir ustalıkla ele aldığı bu soyut kavramları metodolojik olarak felsefenin düşün alanından alarak siyasi ve toplumsal pratiklerle buluşturmakta; ancak, mimari somutlukla temkinli bir bağ kurmakta ve belli bir mesafeyi korumaktadır. Bunun aksi bir metodoloji ile, bu yazı, kamusal mekân ve kamusal beden iç içeliği kuramsallığını çok katmanlı mimari açıımları olan Viyana Müzeler Avlusu bağlamında irdelemektedir.
Bu kamusal mekân, tarihi dokusunu koruyan, ve bu dokuyu oluşturan kentsel nesnelerle gündelik yaşamı örtüştürmeye önem veren başkent Viyana'nın merkezi bir bölgesinde yer almakta ve kentsel kültürün önemli parçasını oluşturmaktadır'. Örneğin, cadde ve sokaklarının önemli kentsel nesnelerinden olan geleneksel at arabaları / faytonlar (pherdekutshen), kent gezginleri için bir çekim yaratmanın ötesinde kentsel hafızayı zaman ve mekân ilişkisi bağlamında korumakta, atlar ve sürücüleri gündelik kentsel yaşamın önemli bir unsuru olan trafik akışkanlığının doğal bir parçası olmaktadır (Görsel 1-2-3).

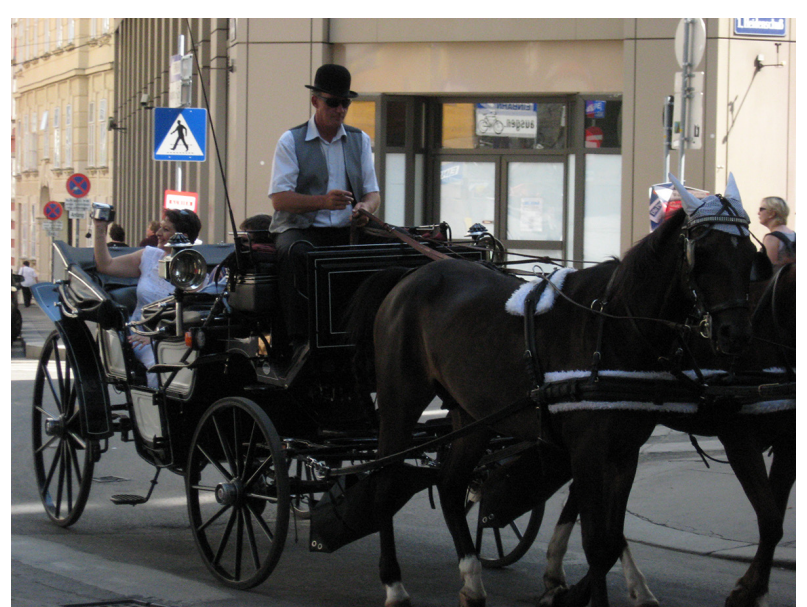

Görsel I. Viyana'nın Kentsel Hafızasının Dikkat Çeken Elemanları: At Arabaları / Faytonlar (Pherdekutshen)

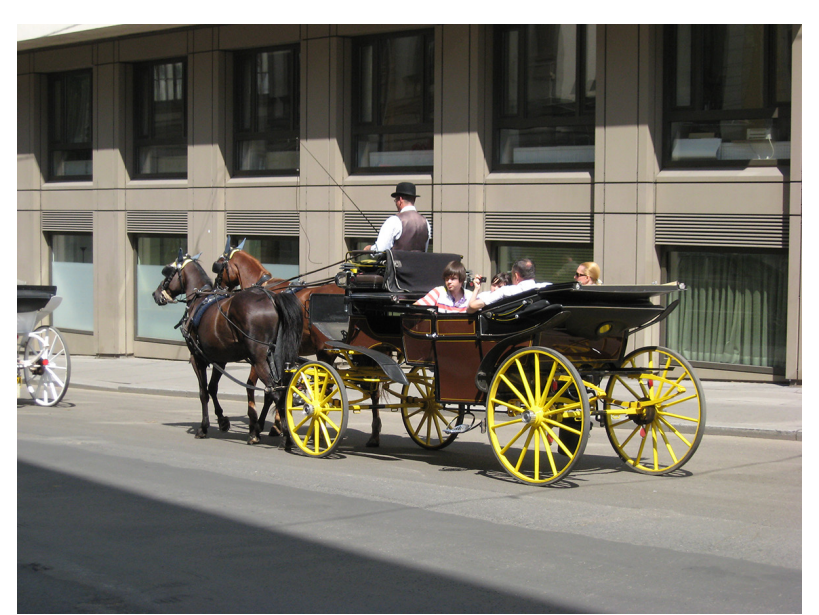

Görsel 2. Viyana Caddelerinde Trafiğin Parçası Olan At Arabaları 


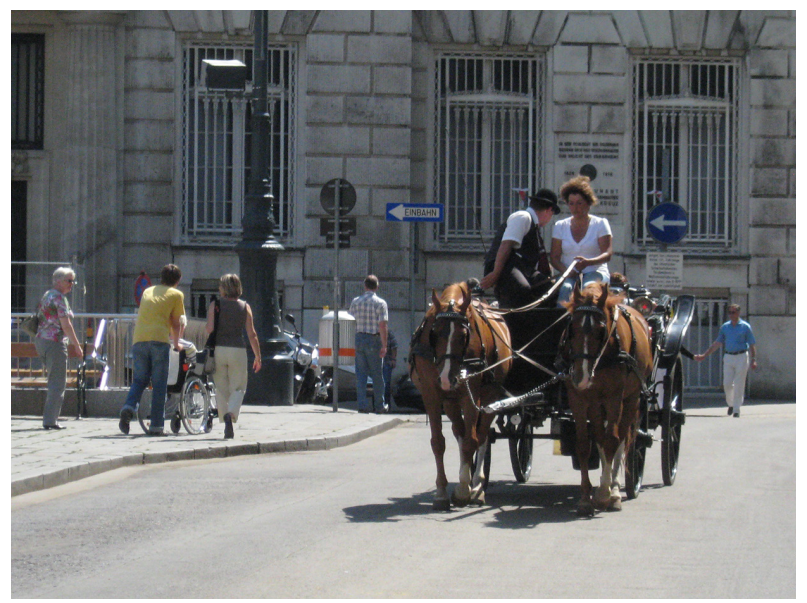

Görsel 3. At arabaları Stephansplatz’ı çevreleyen bölgede yoğunlaşmaktadır.

Viyana'nın kentsel hafızasının ve mekânsal pratiklerin sürekliliğinin temsilcileri olan atlar, bu yazıda ele alınan mekânın hafızasında da sembolik bir konuma sahiptir denebilir. MuseumsQuartier Wien (MQ Wien) olarak bilinen çağdaş sanat ve kültür kompleksi, kraliyetin 18. yüzyıl barok dilini taşıyan ahır kompleksinden (Hofstallgebaude) dönüștürülen bir mimari / kentsel projedir. Şüphesiz, Viyana gibi mekânsal biçimlenmesi mimarlık tarihinin önemli sayfalarını oluşturan kentlere yeni mekânsal öneriler getirmek, bu önerileri mimari olarak hayata geçirmek ve kentlinin mekânsal pratikleri bağlamında öngörülen sosyo-kültürel hedeflere ulaşmak öncelikle kenti doğru okumayı ve iyi çizilmiş yaratıcı bir yol haritası geliştirmeyi gerektirir.

Viyana'yı mimari anlamda (ve mimarlık tarihi alanında) özgün ve diğer Avrupa kentlerinden farklı kılan çok önemli bir özellik, kentte mimari dokuya ağırlıklı şekilde hakim olan yeniden canlandırmacı-tarihselci yapı gruplarına kararlııkla eklemlenen erken Modern mimarlık dilidir. Bu dilin kuramsal yaratıcıları ve kentteki uygulayıcıları Otto Wagner (1841-1918) ve Adolf Loos (1870-1933) gibi modern mimarlık tarihinin Avusturyalı bas aktörleridir. MuseumsQuartier Wien projesinde dikkat çeken bir nokta da, Viyana'nın kentsel dokusunu mimari anlamda özgün kılan bu erken 20. yüzyıl tavrının kentin merkezi bir bölgesindeki bu proje bağlamında yüzyılın sonlarında da devam ettirilmesidir.

Sadece Viyana'nın değil, tüm Orta Avrupa'nın en renkli kamusal mekânlarından olan Viyana Müzeler Avlusu, MuseumsQuartier Wien kompleksinin içinde yer almaktadır. Bu kentsel ölçekteki avlu kendine özgü bir üslupla kentlinin serbest zamanlarına dâhil olan bir açık kamusal mekândır. Serbest zaman (leisure/free time) kavramı her ne kadar antik Yunan toplumuna uzanan kökleriyle tarihselleştirilebilse de (Juniu, 2000), bu kavram ağırlıklı olarak modern zamanların çalışma hayatına parallel gelişen, hatta onunla var olabilen bir yakın dönem fenomeni olarak kuramsallaştırılmaktadır.

Bu yazıda da benimsenen bu kuramsal anlayışta, serbest zamanlar, çalışan bedenleri ve zihinleri çalışmaya verimli şekilde geri döndürebilmek için vardır. Beklenebileceği üzere, serbest zaman kavramının sadece çalışma ve çalışma bileşenleri ile ilişkilendirilerek kuramsallaştırılmasını, bu kavramı 'dar bir çerçeveye indirgemek' olarak niteleyen yaklaşımlar da mevcuttur (Moorhouse, 1989: 15-16). Ancak kavram akademik / bilimsel araştırmalarda farklı disiplinlerce çok yönlü şekilde ele alınmakta ve bu araştırmalar ışığında çalışma-serbest zaman ikililiği farklı noktalardan yaklaşmayı gerekli kılan bir paradigma olarak öne çıkmaktadır. Bu sava dayanarak öngörülebilir ki, modern kentler tarihsel, ekonomik, sosyal ve politik bağlamlarda araştııılı̆ğı gibi, serbest zaman bağlamında da incelenmesi gereken karmaşık bir yapıdadır. Nitekim, özellikle büyük kentlerde çalışma hayatının yoğunlaşmasıyla gündeme gelen serbest zaman kavramı pek çok araştırmaya cinsiyet, ekonomi, aktiviteler, tüketim toplumu, sosyal katılım gibi farklı perspektiflerle konu olmaktadır (örn.,Scraton ve Watson, 2010, Mannel ve Kleibel, 1997; Manrai, 1995; Shaw, 1985; Francken ve Raaij, 1981). Serbest zaman (leisure time) kavramının, serbest zaman mekânı (leisure space) bağlamında tartışılması ise kavrama kentsel kültüre dair bir anlam yüklemektedir (Rojek, 1989: 198-199). Başka bir deyişle, serbest zamanın kavramsal ve fiziksel olarak mekânsallaşması onu kentse kültürün belirleyicisi olan bileşenlerinden biri yapmaktadır. Ve, modern kent yaşamını doğru şekilde çözümleyebilmek için, mekânsal açılımları sayısız kentsel araştırmaya konu olan üretim, yönetim, barınma, eğitim, sağlık gibi, serbest zaman da kentsel örüntüyü ve pratikleri kurgulayan dolayısıyla kentsel kültürü şekillendiren bir bileşen olarak görülmelidir.

Bu çalışmada, serbest zaman kavramı, kentlinin bu zaman dilimleri içinde kamusal mekânları kullanırken bu mekânlara nasıl bir dinamik getirdiğini (ve aynı şekilde bu mekânların serbest zaman bedenlerine nasıl bir dinamik getirdiğini) göstermek için bir bağlam oluşturmaktadır. Bu bağlam, kentin her zaman canlı olan Müzeler Avlusu'nda kamusal mekân ve kamusal beden ikilisinin nasıl bir iç içelikle mekân-beden ilişkisi ürettiğini gözlemleyebilmek için gerekli bir öğe olarak görülebilir. Bu çerçevede, avlu, kamusal mekân ve kamusal bedenin iç içeliğini birinin diğerinin değerini belirlediği bir ilişki olarak ortaya koymaktadır. Bu ilişkide kentli ne mekâna sonradan katılandır, ne de mekânı var edendir; mekân ise ne mutlak bir varoluştur 
ne de Leibniz'in metaforuyla, işgal edilmeden önce 'ayırt edilemez' bir içeriktir. 'Zaman ve mekânın birbirinden ayırt edilir ama ayrılmaz' (Lefebvre, 1974/2014: 192) olması gibi, beden ve mekân bu ilişkide ayırt edilir ama ayrılmaz bileşenlerdir (Görsel 4-5).

Viyana Müzeler Avlusu'nun ürettiği kamusal mekân ve kamusal beden ilişkisinin irdelenmesine geçmeden önce söz konusu alanın tarihsel süreklilik içinde mekânsal bilgisini vermek yerinde olacaktır. Aşağıdaki bölümde, alanın monarşiden demokrasiye uzanan toplumsal süreç dinamiklerine bağlı olarak gerçekleşen dönüşümü siyasal, sosyo-ekonomik ve kurumsal olguları içeren bir ardışıkıkla aktarılmaya çalışılacaktır.

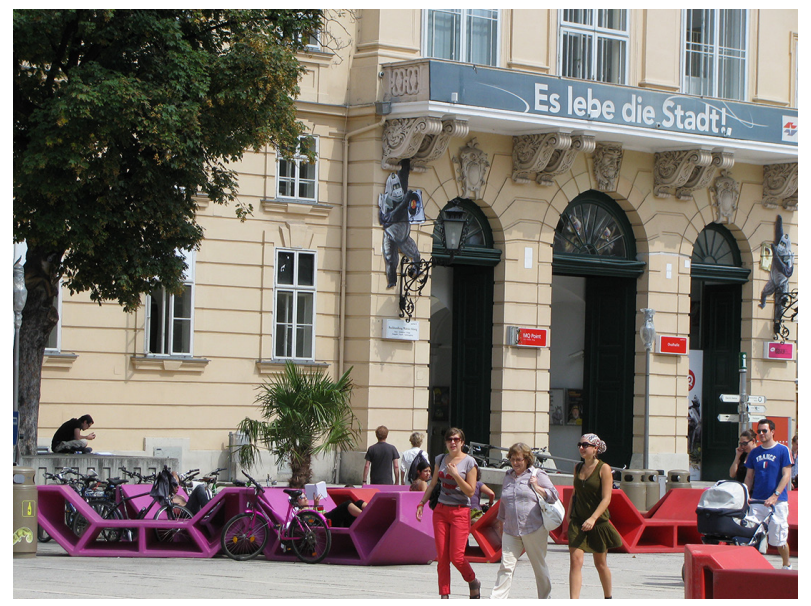

Görsel 4. Viyana Müzeler Avlusu: “Es lebe die Stadt!”: Kent çok yaşa!

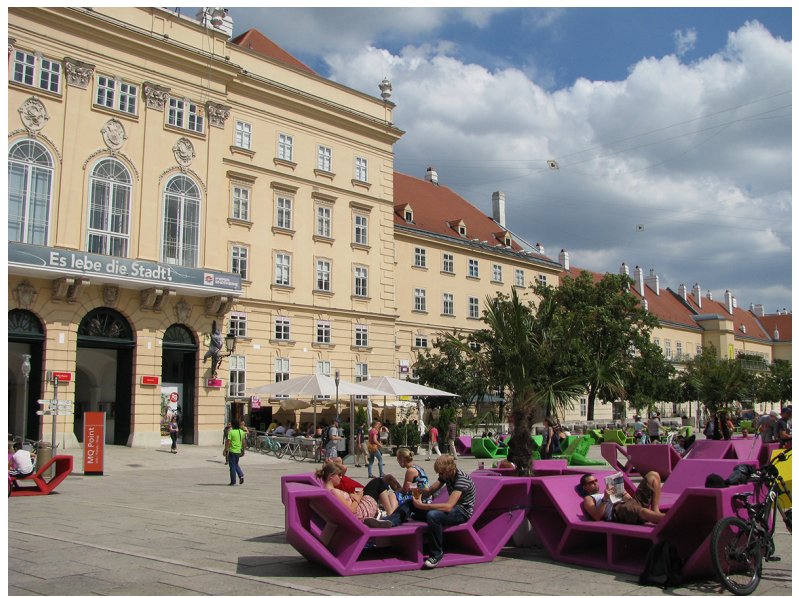

Görsel 5. Viyana Müzeler Avlusu Ve Mekân-Beden İlişkisi
Zaman ve Mekân: Kraliyet Ahır Kompleksinden Müzeler Avlusuna Dönüşüm

MuseumsQuartier Wien Orta Avrupa'nın en büyük ve en önemli sanat ve kültür merkezlerinden biri olarak nitelenmektedir (Boeckl, 2001). Viyana Müzeler Avlusu, sayısı yetmişi bulan sanat ve kültür etkinliklerini barındıran bu kamusal mekânlar bütününün kalbi olarak nitelenebilecek açık alanıdır. Yirmi üç kentsel bölgeden oluşan Viyana'nın yedinci bölgesinde (7. Gemeindebezirk) yer alan ve çeperlerini farklı dönemlerde inşa edilmiş müze ve kültür yapılarının tariflediği bu açık kentsel alan sanat, mimarlık, yaratıcılık, gündelik yaşam, serbest zaman ve gökyüzü bileşenlerinden oluşmaktadır. Avlunun ana girişinin bulunduğu ince uzun 18. yüzyıl yapısı, Viyana'nın eski kent merkezini çembere alan Ring Caddesi'ne paralel ikinci bir halka oluşturan Müze Caddesi (Museumplatz Strasse) boyunca uzanmaktadır. Bu barok ana cephenin karşı parselinde 1871-1891 yılları arasında karşılıklı inşa edilmiş olan ünlü mimar Gottfried Semper ve Karl Freierr von Hasenauer'in neo-barok ikiz müzeleri Doğa Tarihi Müzesi (Naturhistoriches Museum) ve Sanat Tarihi Müzesi (Kunsthistoriches Museum) bulunmaktadır. Avlunun ana giriş aksının eski kent merkezi (Innere Stadt) yönündeki devamında tarihi kraliyet sarayı (Hofburg) yer almaktadır (bugünkü Cumhurbaşkanlığı Sarayı ve sarayın yanı sıra Efes Müzesi -Ephesos Museum Wien, Dünya Müzesi -Weltmuseum gibi kültürel mekânlar ve her yıl üç yüzden fazla etkinlik barındıran kongre merkezi -Hofburg Kongresszentrum Wien) (Görsel 6).

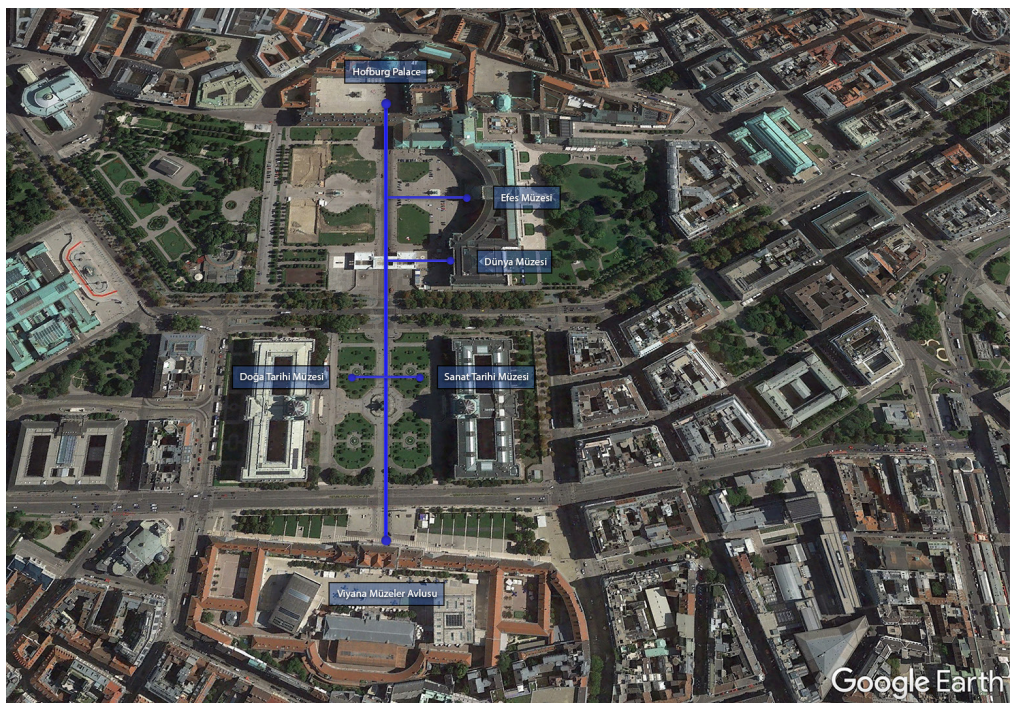

Görsel 6. Viyana Müzeler Avlusu'nun Ana Cephesindeki Girişten Kent Merkezine Doğru Yönlenen ve Bir Grafikle Gösterilen Aksta Sırasıyla İkiz Müzeler ve Hofburg Alanı 
Ana avluya bağlı daha küçük iç avluları tarifleyen yan cephelerinden biri kentin gündelik yaşamının en hareketli yerlerinden olan Mariahilfer Caddesi'ne (Mariahilfer Strasse) açılmaktadır. Diğer yan kısa cephe Burg Sokağa (Burg Gasse), arka uzun cephe ise birbirine bağlanan Breite ve Karl-Schweighofer Caddelerine (Breite Strasse Karl-Schweighofer Strasse) açılmaktadır. Çok geniş bir alana yerleşen avlunun mekânsal canlılığında, geçirgen bir tektonik yapıya sahip olmasının ve dört farklı yönden değişik kullanımlara ve niteliklere sahip kent parçalarından beslenmesinin rolü büyüktür (Görsel 7).

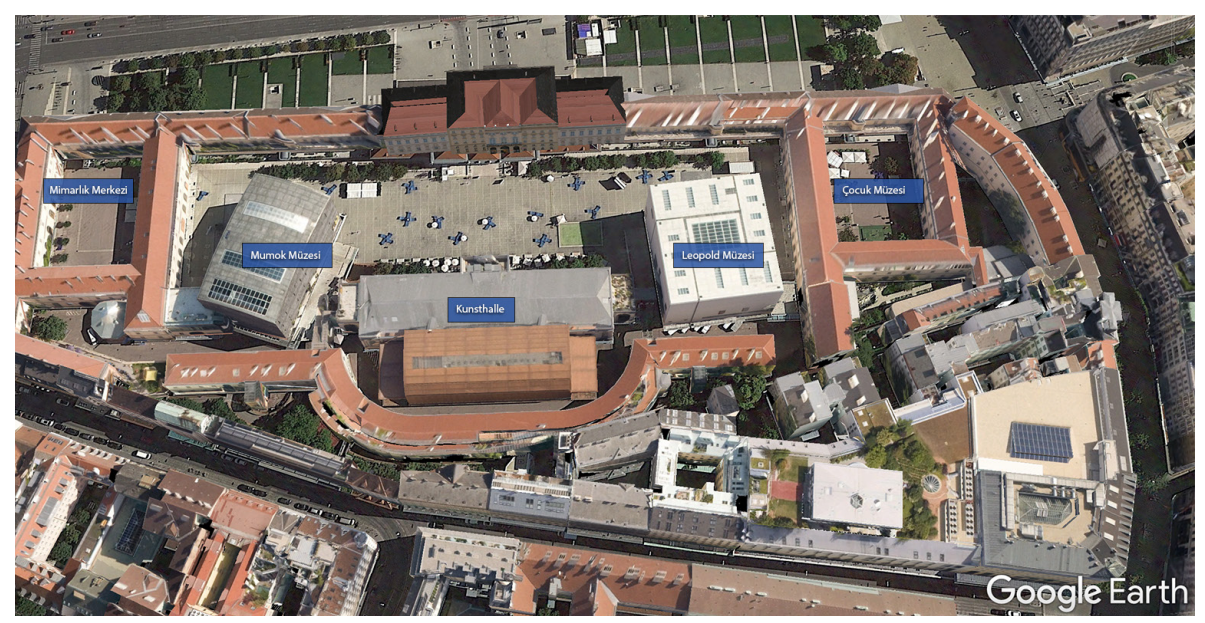

Görsel 7. MuseumsQuartier: Eski Ahır Kompleksi İçinde Viyana Müzeler Avlusu, Yan Avlular, MUMOK, Leopold Müzesi ve Kunsthalle

2001 yılından itibaren sanatla, entellektüel etkinliklerle ve serbest zaman aktiviteleriyle anılan MuseumsQuartier aslında üçyüz yıllık ilginç bir kentsel hafızaya sahiptir; geçmiş yüzyıllarda, önce bir kraliyet çiftliği olarak kanatlı hayvanlara, sonra kraliyetin barok mimari üsluplu ahır kompleksi olarak atlara ve binicilikle ilgili pek çok faliyete, daha sonra ise çeşitli büyük çapl fuarlara ev sahipliği yapmıştır. Kentlerin kültürel bağlamda yenilenme talepleri mekânsal dönüşümü de beraberinde getirir. Yüzyıllar içinde değişen sosyal koşullara, kullanım taleplerine ve yeni mimari/kentsel anlayışa bağlı olarak üç büyük dönüşüm geçiren MuseumsQuartier alanı, bu anlamda önemli bir örnek teşkil etmektedir (Reicher, 2016: 35-37).

Bugün MuseumsQuartier ${ }^{2}$ olarak adlandırılan alan, 1713 yılına kadar kraliyet ailesine hizmet amacıyla faliyette bulunan kanatlı hayvan çiftliğini

${ }_{2}^{2}$ MuseumsQuartier'in resmi internet sayfasına www.mqw adresinden ulaşlabilir. MQ Chronik. (2017). Web: https://www.mqw.at/ueber-uns/chronik/ adresinden I Mart 20I7'de alınmıştır.
(Kaiserlicher Geflügel-hof) ve geniş bahçeleri barındırmıştır. Bu tarihte, Kaiser VI. Karl'ın (1685-1740) talimatıyla, alanı 600 at barındıracak ahır ve at çiftliğine (Hofstallgebaude) dönüştürmek üzere Avusturyalı ünlü mimar Johann Bernhard Fischer von Erlach (1656-1723) tarafından çalışmalar başlatılmışır. 1722 yılından sonra inşa çalışmalarını oğlu Joseph Emanuel von Erlach (1693-1742) üstlenmiş ve uzun yıllar kraliyet ailesinin mimari beğenisini şekillendiren babasının hazırladığı planlarda bazı küçük değişiklikler yapmıştır (Zacharias, 1960: 77). 1725'de 350 $\mathrm{m}$ uzunluğundaki ana cephe tamamlanmıştır. 1809'da I. Napolyon'un Viyana işgali sırasında Fransız askerlerine korunak görevi yapan ahır ve çevresi bu kuşatma döneminde ağır savaş hasarları görmüş ve 1815'de restorasyona alınmıştır (Czeike, 1994: 239). 1850-1854 yılları arasında Kaiser Franz Joseph I'in (1830-1916) Leopold Mayer'i görevlendirmesiyle ahır kompleksi kraliyet binicilik okuluna dönüştürmek üzere genişletilmiş ve yeniden tasarlanmıstır (Wehdorn, 2004: 140). 1874 yilında Kaiserin Elisabeth (1837-1898) kendisinin de binicilik dersleri aldığı manej alanında yenilemeler yaptırmıştır (Görsel 8).

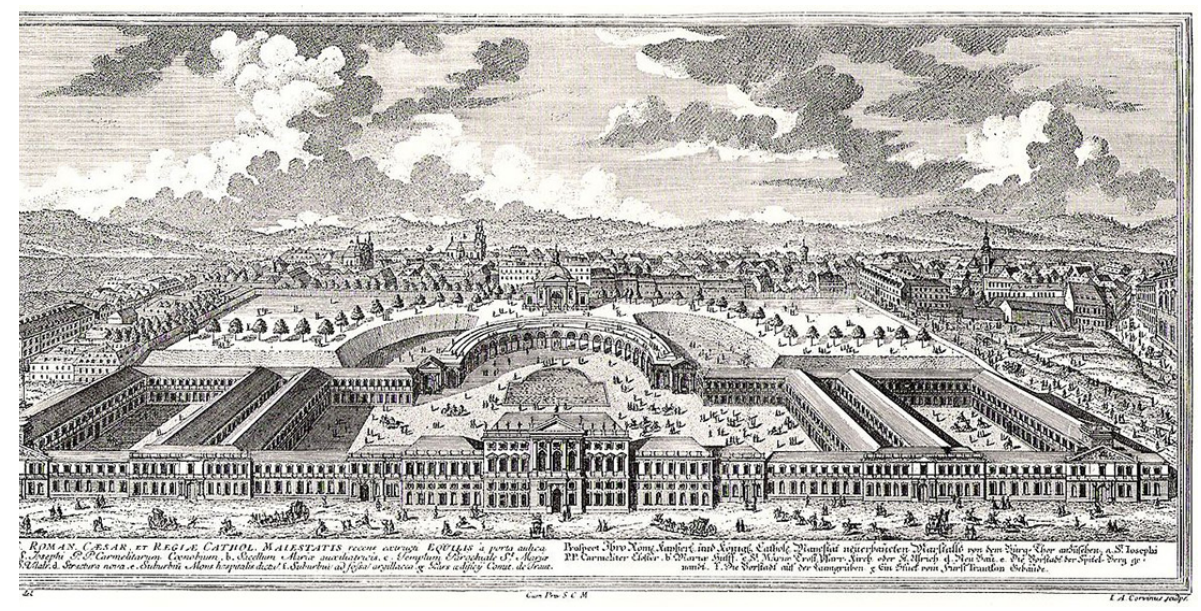

Görsel 8. Johann Andreas Pfeffl (Salomon Kleiner’i Esas Alarak), Kraliyet Ahır Kompleksi Hofstallgebaude, I724, Bakır Üzerine Gravür

Birinci dünya savaşı sonunda 1918'de Avusturya-Macaristan monarşisinin sona ermesi ve birincicumhuriyet döneminin başlamasıyla ahır kompleksinin mal varlığının büyük bir bölümü açık arttırmayla satışa çıkartılmıştır. 1921 yılında kraliyet ahır kompleksi (Kaiserliche Hofstallungen), Viyana Fuarı'nın (Wiener Messe) sergi alanlarından biri olarak kullanılmaya başlanmıştır. Komplekste mekânsal dönüşümler yapılmış, büyük bir sergi mekânı eklenmiş ve alan Wiener Messepalast adıyla anılmaya başlanmıştır. Başta 
ilkbaharve sonbahar fuarları (Frühjahrs-Herbstmesse) olmaküzere pek çok özel temalı fuarlar bu alanda gerçekleştirilmiştir (Czeike, 1994: 338-339). Avusturya'nın Almanya'ya katıldığı ikinci dünya savaşı yıllarında (19381945) bu alan siyasi propaganda amaçlı gösteri alanı olarak kullanılmıştır. Savaş sonrası yıllarda alana yeni yapılar eklenmiş ve fuar faliyetine geri dönülmüştür.

Alanın bugünkü sanatsal kimliğiyle buluşması, 1977'de buradaki yapıların Avrupa'nın önemli sanat koleksiyonlarına (Ludwig Koleksiyonu gibi) ev sahipliği yapabilme potansiyelinin parlamentoda ulusal çapta tartışılması ile başlamışıtır. Bu tartışmaların belirleyici unsuru, federal hükümetin kültürel ve ekonomik politikaları çerçevesinde, Barok ahırlardan fuar alanına uzanan geçmişi ile kentin kıymetli bir bölgesinde bulunan bu alanın canlandırılabileceği gerçeğidir. Bu süregelen tartışmaların bir sonucu olarak 1983 yılında, dönemin Bilim Bakanı Heinz Fischer alanda bir kültür kompleksi (Kulturforum) oluşturulmasının önünü açmış ve iki yıl sonra bu alan, Viyana kültür ve sanat etkinlik haftalarına (Wienerfestwochen) ilk kez ev sahipliği yapmışıı ${ }^{3}$.

Avrupa'nın önemli başkentlerinden Viyana'da, çok merkezi bir konumda, tarihsel dokuya ve özel bir hafızaya sahip olan, ama kullanım pratiklerine bağlı olarak bu niteliklerin hakkıyla hissedilemediği bu alanın dönüştürülmesi stratejisinin, siyasal ve sosyo-ekonomik açlımlardan bağımsız olacağı düşünülemez (Frantz, 2005: 54). Bu yıllarda, alanın nasıl dönüştürülebileceği yolunda, alışveriș merkezi ve otel gibi ticari kullanımları da kapsayan pek çok tartışma yapılmıştır. Ancak, alanın kültür-sanat ağırlıklı bir programa sahip olması fikri ağırlıklı olarak benimsenmiștir. Kültüre dinamikler kullanılarak, alanın, sanat ağırlıklı geliștirilmesi ve yapısal olarak yenilenmesi yolundaki siyasal ve bürokratik kararlıı̆ı̆ın en güçıü işareti ilgili federal bakanlık tarafından 1986 yılında açılan modern sanat müzesi ve sergi alanları, iki aşamalı mimari proje yarışmasıdır.

H. Hollein, O. M. Ungers, J. Herzog ve P. de Meuron gibi ünlü mimarların katıldığı yarışmada, kardeş Avusturyalı mimarlar Laurids Ortner ve Manfred Ortner'in alanın tarihsel kimliğiyle çarpıcı bir kontrast yaratan tasarımları jürinin oy birliğiyle birincilik kazanmışıı (Reith, 1988). Yarışma sonrasında alana yönelik tartışmalar dinmemiş, ancak tartışma politik zeminden mimari zemine taşınmışı.ı. Yarışmayı kazanan mimarların 60000 metrekarelik bu büyük alandaki mekânsal önerileri tarihsel dokuyla uyum sorunu yaratacağı gerekçesiyle eleştirilmiştir. İnşa edilmesi uzun yıllar süren (1998-2001) alan

3.MQ Chronik. (2017). Web. https://www.maw.at/ueber-uns/chronik/ adresinden I Mart 20I7'de alınmıştır. mimari anlamda son halini almadan çok önce, 1989'da Bilim Bakanı Erhard Busek'in MuseumsQuartier Wien adını ilk kez zikretmesiyle kültür ve sanat çağrışımlı bir isime ve 1990 'da federal parlamentoda onaylanmasıyla da ulusal bir statüye kavuşmuştur ${ }^{4}$.

Tarihi ahır yapıları dizininin farklı cephelerde farklı yüksekliklerde, ancak güçlü bir tektonik süreklilikle sınırlarını çizdiği bu avluda MUMOK modern sanatlar müzesi, koyu antrasit bazalt (volkanik taş) kaplama cepheli kütlesiyle ve bu kütlesel imgeyi destekleyen az sayıdaki cephe açıklıklarıyla içe dönük bir anlayışla tasarlanmıştır. Müze yapısı özgün biçimlenmesiyle adeta içinde sergilediği (geleneksel sanat anlayışının dönüşümünü simgeleyen) çağdaş sanat koleksiyonunun mimari form bağlamında etkili bir dışa vurumudur. Köşelerinden hafifçe aşağı çekilmiş gibi duran dikdörtgen prizma yapı kendine özgü bir geometrik kompozisyonla tarihi binalardan tamamen farklı bir üslubu özgüvenle teşhir etmektedir. Avludaki tarihsel katmanlanma, müzenin var olan tektonik doku içindeki yerleşimiyle daha okunaklı hale gelmekte, eski ve yeni, çağdaş bir estetik anlayışla birbirine tutunmaktadır.

Avlunun diğer önemli yeni yapısı beyaz küboid Leopold Müzesi erken 20. yüzyıl modern mimarlık anlayışının sade bir yorumu niteliğindedir. Pek çok perspektiften tarihi cephelerin algısına dingin bir fon gibi katk sağlayan müze sahip olduğu cok özel ve dünya çapında zenginlikteki sanat koleksiyonunu alçakgönüllü bir zarf gibi sarmalamaktadır. Benzer sekilde, avlunun iç çeperini olusturan tarihi barok cepheler de yeni yapıların algııını güçlendiren bir fon oluşturmaktadır. Ait oldukları dönemin iyi birer temsilcisi olan bu yeni yapılar ve farklı kültürel işlevlere göre iç mekânlar yeniden düzenlenmiş barok yapılar tarihi avluyu zaman ve mekân ilişkisi bağlamında güçlü bir çerçeveye yerleştirmektedir.

\section{Devinimli Bir Kamusal Mekân}

Adının da vurgulağı üzere, Viyana Müzeler Avlusu, mekân ve beden ilişkisini bir grup müzenin tanıklığında geliştirmektedir. Müzeler söz konusu olduğunda sıklıkla dile getirilen bir argüman, müzelerin bir bina olmaktan öte kentin parçası olduğudur. Bunun temelinde yatan anlayış, müzelerin eğitici rollerinin yanında, bireye keyif veren kamusal mekânlar olma potansiyelidir. Bu anlayışla üretilen müzelerin mimari kurguları bu önemli kamusal mekânların kentle ilişkisini önceleyen farklı ifadelere sahiptir. Bu argümana destek veren mimari kurgulardan biri, birden fazla müzenin bir

${ }^{4}$ MQ Chronik. (2017). Web. https.//wwwmaw at/ueber-uns/chronik/ adresinden I Mart 2017'de alınmıștır: 
araya gelerek ortak alanlar, mekânsal geçişler oluşturması ve birbirleriyle görsel iletişim kurmasıdır (Tzortzi, 2016: 37).

Elbette, MuseumsQuartier (Müzeler Bölgesi) gibi sanat ve kültür odaklı büyük projelerin mimari kurgusu, parçası oldukları kentlerin kültürel (ve ekonomik) siyasetleriyle de ilişkilidir. Bu projeler bir yandan kentliye canlı kamusal mekân olanakları sunarken bir yandan da rekabet içindeki çağdaş kentlere ekonomik ve sosyal kalkınmalarında sembolik stratejiler olarak hizmet vermektedirler (Frantz, 2006: 237). Viyana Müzeler Avlusu bu mimari anlayışın ve kültürel siyasetin en önemli temsilcilerinden biri olarak nitelendirilebilir.

Dünyanın çeşitli bölgelerinde ve farklı tarihsel süreçlerde benzer anlayışla kurgulanmış kompleksler, yer aldıkları kentsel çevreyi ve hatta, kentsel kültür ve ekonomik katkı bağlamlarında, kentin bütününü ve kentliyi etkilemektedir. Müzeler, kültürel, sanatsal, tarihsel ve bilimsel içeriklerin özgün şekilde ziyaretçilere sunulduğu temsil mekânları olmakla kalmayıp, kentlerde ekonomik büyümenin sürdürülebilmesinin önemli nesneleri olmaktadır (Santagata, 2002). Bu çerçevede, eş zamanlı projelendirilen ya da farklı dönemlerde ancak bir kentsel komşuluk ilişkisinde olusturulan, dolayısıylabirarayatoplanarak/yakınlaşarakbirbirindenbeslenenmüzelerin, tariflenmiş ve çoğunlukla da 'adlandırılmış' kültür bölgeleri niteliğindeki örnekleri kadar, heykelsi bir tektonik dille ve seçkin koleksiyonlarla kenti sarmalayan örnekler de hatıllanabilir. Frank Gehry'nin küresel üne sahip mimari tasarımıyla ve baskın ölçeğiyle, kentinin endüstriyel kimliğini bütünüyle kültürel bir kimliğe dönüştüren Guggenheim Modern ve Çağdaş Sanat Müzesi (1997) bu kültürel stratejinin en öne çıkan temsillerindendir (Plaza, 2000; Ceballos, 2004). Bu yaklassımın daha erken bir örneği, döneminin en ünlü mimarlarından Frank Lloyd Wright imzalı New York Guggenheim Müzesidir (1959) (Levine, 1996). Tüm iç mekânı saran spiral bir rampa yoluyla avant-garde eserlerin izlenebileceği bu müze yapısı, kentin kültür ve mimarlık sembolü niteliğindedir. Ancak, bu tekil temsil mekânları Viyana örneğinde incelenen kentsel bağlam ve kentli ile kurulan kentsel bağ anlamlarıyla dolaylı olarak ilişkilendirilebilinir.

Viyana örneğinde öne çıkan ve bu çalışmada irdelenen niteliklere daha yakın tutumlar sergileyen kamusal mekânlar ise müzeleri seçkin binalar olmaktan çok kentin doğal parçası kılan ilişkileri öncelemektedir. Bu noktada, kendi içinde farklılaşan ama kültürel anlamda kentsel gelişimi ve kent pratiklerini etkileyen, çeşitli beden-mekân ilişkisi önermeleri sunan bazı 'kültürel kent parçalarına' kısaca bakılabilir. Örneğin, Almanya'da, bugünün Berlin'inde merkezi bir konumda bulunan Berlin MuseumsInsel (Müzeler Adası)
Spree Nehri boyunca uzanmakta ve beş müze yapısından oluşmaktadır. Tarihi 19. yüzyıla dayanan bu kültür adasının ilk müze yapısı Karl Friedrich Schinkel tarafından tasarlanıp inşa edilen ve bugün önemli bir antika koleksiyonunu barındıran Altes Museum'dur (1830). Adanın ikinci büyük müzesi Friedrich August Stüler'in tasarladığı Neues Museum'dur (1855). Müze Mısır kültürüne ait geniş bir sergi ve zengin papirüs koleksiyonu ile bilinmektedir. İkinci müzenin inşasıyla bu bölge 'kültür-sanat-bilim' merkezi olarak nitelenmiş ve Almanya'nın kültürel siyasetinin kentsel bir simgesine dönüşmüştür. Adada yer alan Alte Nationalgalerie (1876) resim ve heykel koleksiyonuna, Bode Museum (1904) para koleksiyonuna ve Pergamonmuseum (1930) arkeolojik antik eserlere evsahipliğiyapmaktadır. Yılda yaklaşık dört milyon ziyaretçiyi ağırlayan bu kültür adası, Berlin'in en önemli kamusal mekânı ve kentsel cazibe merkezidir. Turistler kadar kent sakinlerini de serbest zamanlarında kendisine çeken bu mekân kentle bütünleşmiş bir dokuya sahiptir5.

Birer müzeyapısı olmanınötesinde kentibütünleyenönemlibirbileşen olarak nitelenebilecek bir kültür kompleksi de uluslararası sanat merkezlerinden ve Roma döneminin tarihsel mirasçılarından Köln'de yer almaktadır. Kentin mimarlarından Peter Busmann ve Godfrid Haberer tarafından tasarlanan ve inşa edilen Museum Ludwig (1986) ve Walraf-Richartz Museum'da (1986) sırasıyla, 20. Yüzyıl sanat eserlerini ve Ortaçağ Avrupası resim koleksiyonu sergilenmektedir. Müze kompleksinin diğer yapısı olan Roman-Germanic Museum (1974) Heinz Röcke ve Klaus Renner tarafından tasarlanmıştır. Bugüne kadar 20 milyon kişi tarafından gezilen müze, Roma dönemi gündelik yaşamına ait nesneleri ziyaretçilerle buluşturmaktadır ${ }^{6}$. Köln katedralinin hemen yanındaki konumu ve zengin sergi içerikleri ile bu müzeler grubu kentin en çekici uğrak yerlerindendir. Müzeler arasındaki açık ve yarı kapalı alanlar, alışveriş bölgesine ve merkez gara açılan geçişler, katedralin önündeki büyük kentsel meydanla ve diğer bir yönden Altstadt (şehrin tarihsel bölgesi) ve Rhein Nehri ile kurulan dinamik mekânsal geçirgenlikler müzeler grubunu kente ve kentlinin gündelik yaşamına eklemlendirmektedir. Başka bir deyişle, kentlinin gündelik yaşamı buradaki kültürel ortamla iç içe geçmekte, beden ve mekân ilişkisi sadece kentlinin serbest zamanlarında değil, farklı bağlamlarda, ancak, hep bir doğallıkla kurulmaktadir ${ }^{7}$.

Museumsinsel Berlin-Mitte. (2017). Web: https://www.berlin.de/museum/3 109074-2926344 museumsinsel-berlinmitte.html adresinden 19 Kasım 2017 'de alınmıştır.

'Museumsstadt Koln. (2017). Web: https:I/Www.koeln.de adresinden 20 Kasım 2017'de alınmısstır. Bu kentte dört yıl ikamet etmek kentsel kültürel dokuyu ve kentlinin gündelik yaşamının bu dokuyla nasıl kesiştiğini deneyimlemek olanağııı sağlamıştıı. 
Bu çalışmanın irdelediği Viyana Müzeler Avlusu'nun mekânsal örgütlenmesi ve bunun kentliyle kurduğu kültürel bağ ile tam bir paralellik göstermese de, Ankara 'Müze Yolu' bu bağlamda değinilmesi anlamlı olacak özgün bir kentsel nitelik sergilemektedir. Kale çevresinde yer alan Anadolu Medeniyetleri Müzesi, Rahmi Koç Müzesi ve Erimtan Müzesi'nin oluşturduğu kültürel doku, Viyana örneğindeki gibi bir büyük mimari proje bütünlüğ̈̈nde değildir ancak konumsal yakınlıkları nedeniyle 'Müze Yolu' olarak betimlenmekte ve kentin tarihsel olarak hali hazırda önemli bu bölgesini nitelikli serbest zamanlar geçirilecek bir odak olarak yeniden ve daha güçlü sekilde gündeme getirmektedir. Viyana Müzeler Avlusu'nun işlevsel olarak dönüştürülmüş tarihi yapılarının Viyana'nın kentsel hafızasını koruması gibi, Müze Yolu'nu tarifleyen üç müze de eski yapılar dönüştürülerek elde edilmiş, dolayısıyla, Ankara'nın tarihsel kimliğinin izleri mekânsal olarak sürdürülür kılınmıştır. Kalenin dış duvarlarının güneydoğusunda Yol'un başlangıç noktasını oluşturan Anadolu Medeniyetleri Müzesi iki adet 15. Yüzyıl Osmanlı yapısından (Mahmut Paşa Bedesteni ve Kurşunlu Han) dönüştürülerek elde edilmiş ve 1943 'de ziyarete açılmıştır. Kale kapısının hemen karşııında yer alan Rahmi Koç Müzesi ${ }^{8}$, günümüze kadar özgünlüğü korunmuş Çengel Han'ın (1523) restore edilmesiyle 2005 yılında müze işlevine kavusmuştur. Koç Vakfı'nın satın aldığı Safran Han (1511) da 2016 yılında tamamlanan restorasyonuyla müzenin eklentisi olarak işlevlendirilmiştir. Kale girişine ulaşan yokuşun hemen başındaki üç tarihi evin dönüştürülmesi yoluyla elde edilen Erimtan Arkeoloji ve Sanat Müzesi ${ }^{9}$ projesi Ayşen Savaş, Can Aker ve Onur Yüncü'nün imzasını taşımaktadır. Mimarlar bu dönüşümü özellikle evlerin dış duvarlarının tektonik karakterine ve kentsel/mimari ölçeklerine sadık kalarak gerçekleştirmiştir. Her biri farklı koleksiyonları barındıran müze yapılarının oluşturduğu 'Müze Yolu' kentlinin mekânsal pratiklerine kültürel bağlamda ortak bir zemin vermiştir. Bu zemin, kentin farklı tarihsel katmanlarına eş zamanlı açıımların deneyimlenebileceği çağdaş bir kentsel bağ niteliğindedir.

Bu çerçevede, Viyana Müzeler Avlusu'nda yer alan üç müze yapısı da sanatın farklı anlayış, akım ve ürünlerini kentliyle ve sanat gezginleriyle buluştururken, tarihsel Viyana'nın çağdaş yüzüne de kayda değer bir katkı sağlamaktadır. Leopold Müzesi Viyana Sesesyon Hareketi, Viyana Modernizmi ve Avusturya kaynaklı Ekspresyonizmi /dışavurumculuğu temsil eden eserlerle; MUMOK (Museum Moderner Kunst Stiftung Wien) Orta Avrupa'nın en büyük modern sanat eserleri koleksiyonuyla;

${ }^{8}$ Endüstriyel Mirasin Aynası. (2017). http://www.rmkmuseum.org.tr/cengelhan/turkce/rmk tarihce. htm adresinden 20 Kasım 2017'de alınmıştır.n 20 Kasım 2017'de alınmıştır.

${ }^{9}$ Erimtan Arkeoloji ve Sanat Müzesi. (2017). Web: http://www.arkitera.com/proje/4385/erimtan-arke-

oloji-ve-sanat-muzesi adresinden 20 Kasım 2017'de alınmıștır.
Kunsthalle Wien ise uluslararası çağdaş sanat sergileriyle öne çıkmaktadır. Leopold Müzesi'nde sergilen Gustav Klimt (1862-1918), Oskar Kokoschka (1886-1980) ve Egon Schiele (1890-1918) koleksiyonu 20. yüzyılın bu çok önemli Avusturyalı sanatçılarının en kapsamlı şekilde temsil edildiği müze olarak bilinmektedir ${ }^{10}$. Özzellikle Viyana ile özdeşleşmiş bu sanatçıların eserleri her yıl milyonlarca sanat ziyaretçisinin ilgi odağını oluşturmakta, bu ziyaretçiler aynı zamanda MuseumsQuartier avlusunun da kullanıcısı olmaktadır (Görsel 9).

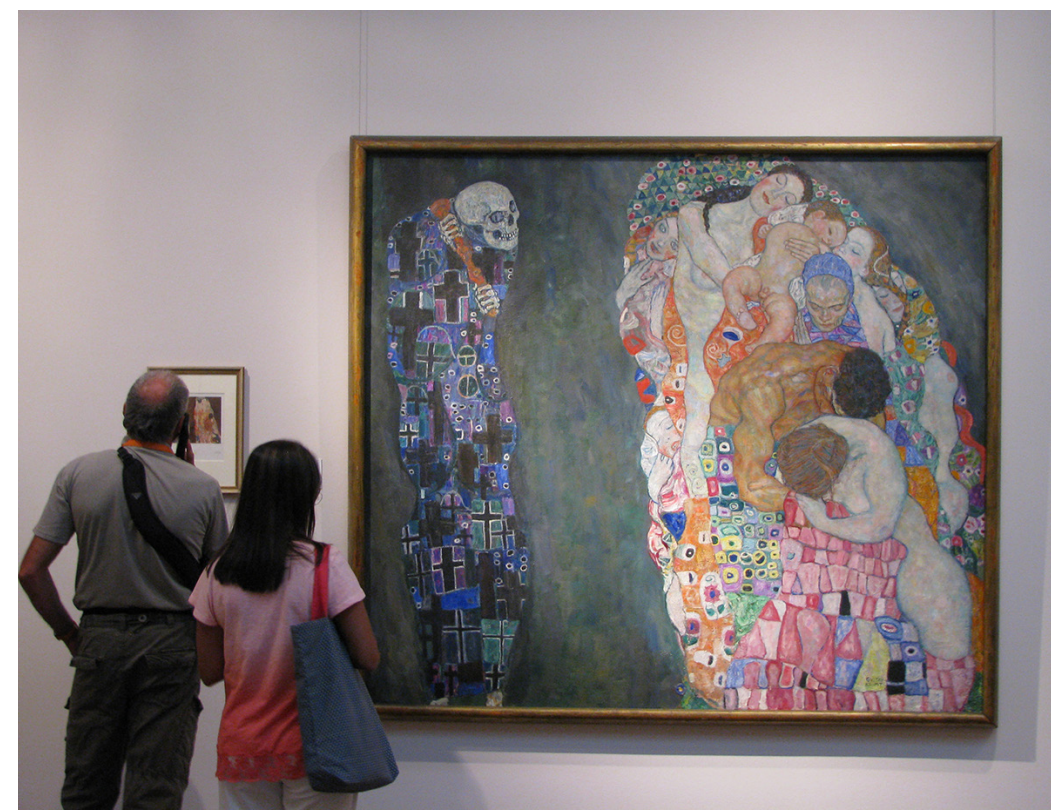

Görsel 9. Leopold Müzesi'nde Viyanalı Sanatçı Gustav Klimt'in Death And Life (1910) Eseri ve Sanat Ziyaretçileri

Çağdaş sanat etkinliklerine yer veren devinimli programları ve çok yönlü sergi içerikleriyle Kunsthalle, bu iki müzenin kalıcı sergi anlayışını tamamlar nitelikle bir canlııkla avlu ile iletişimdedir. Tüm bu mekânların sanatsal içeriği, ortaklaşa paylaştıkları avlunun zemininde kentsel gündelik hayata doğal şekilde sızmaktadır. Benzer şekilde, kentin farklı bölgelerine pasajlar ve yan avlularla mekânsal açııımları olan ana avlunun gündelik yaşam dinamiği müzelere sızmakta ve bunları, sanatı korumaya almış temsil mekânları olmaktan çıkarıp kentsel nesnelere ya da daha doğru bir ifadeyle kentin doğal parçalarına dönüştürmektedir (Görsel 10-11-12).

${ }^{10} \mathrm{MQ}$ Institutionen. (2017). Web: https://www.maw.at/institutionen/ adresinden 7 Mart 2017'de alınmıştır 


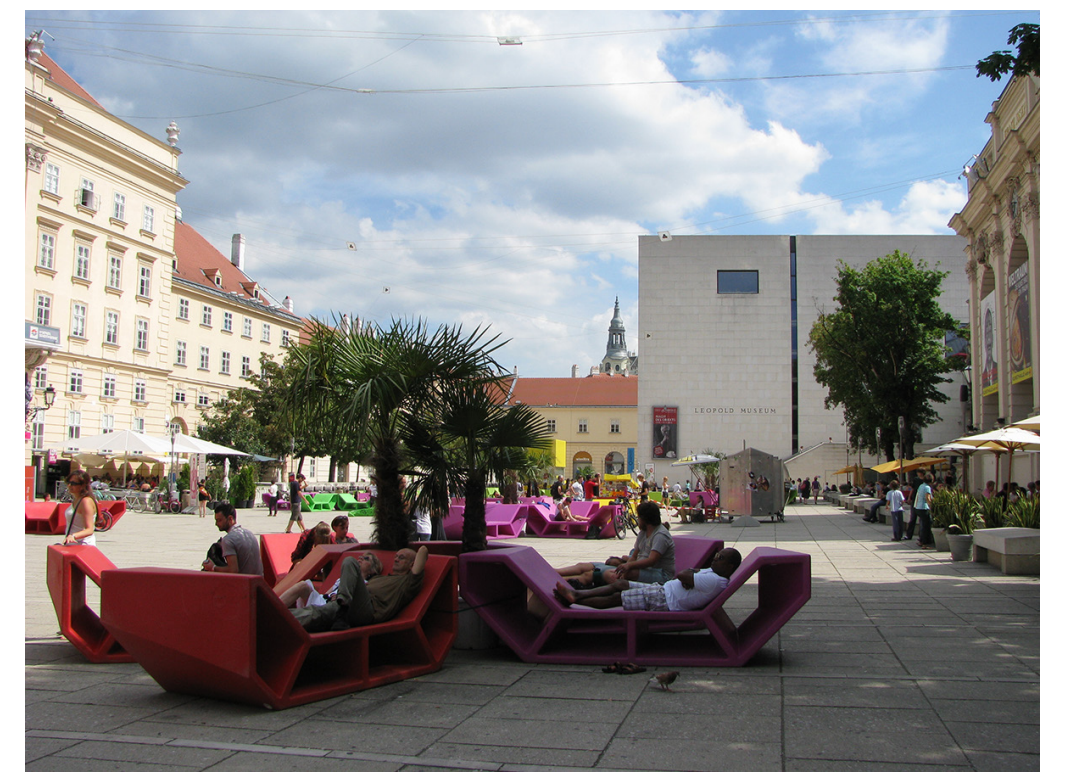

Görsel 10. Viyana Müzeler Avlusu ve sağda Leopold Müzesi

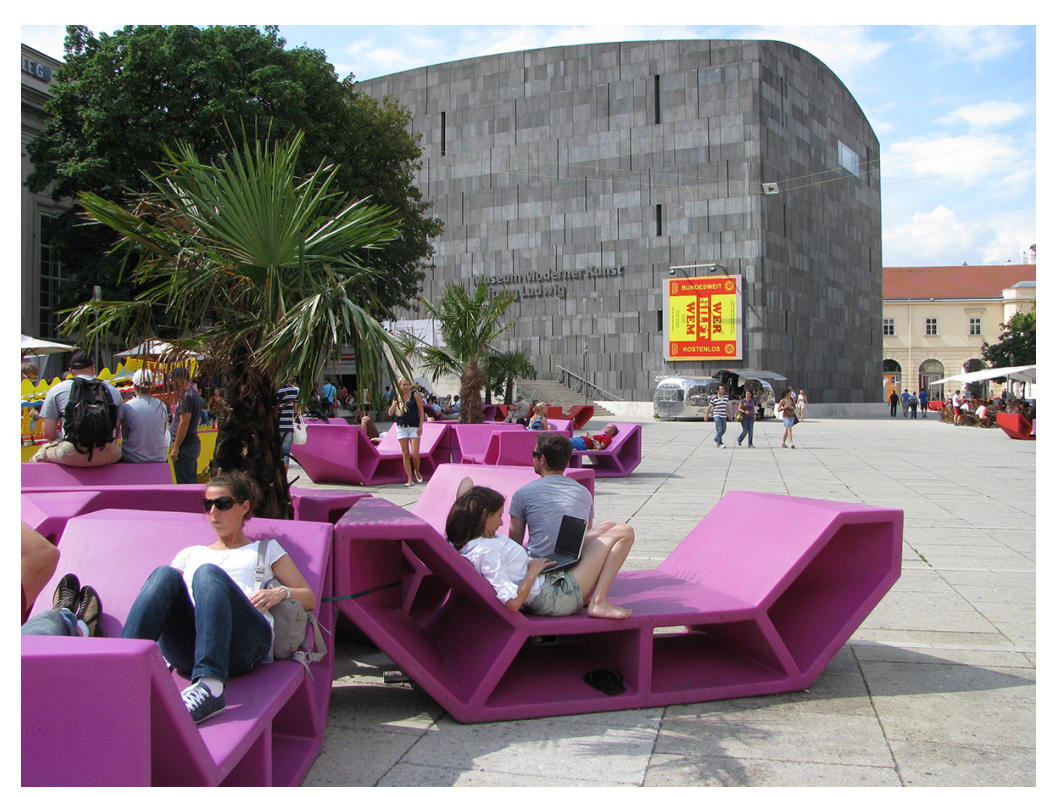

Görsel II. Viyana Müzeler Avlusu ve MUMOK Museum Moderner Kunst Stiftung Wien

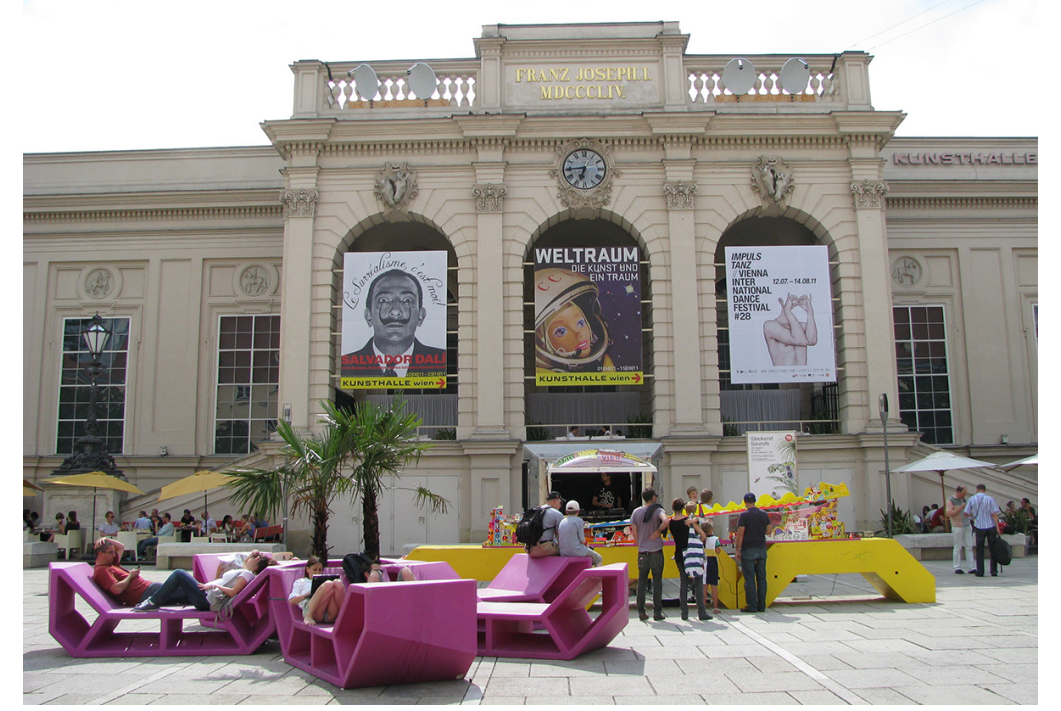

Görsel I2. Viyana Müzeler Avlusu'nda sergi ve etkinlikler için kullanılan Viyana Sanat Merkezi yapısı Kunsthalle Wien

Ana avluyu anlamlandıran başlıca yapılar Kunsthalle Wien, Leopold Müzesi ve MUMOK olmakla birlikte, MuseumsQuartier'ın kentsel çeperlerini tarifleyen tarihi yapılarda yer alan zengin kültürel ve sanatsal işlevler farklı kesimleri avluya çekmektedir. Bu çeperlerdeki cadde ve sokaklara bağlanan yarım silindir biçiminde tonoz örtülü barok pasajlar, edebiyat, sokak sanatı, karikatür, tonal sanat, baskı ve dizgi tasarımı gibi farklı temalarla ana avluya açılmaktadır. Tarihsel pasajlardaki bu temalar değişik ilgi alanları olan kentli gruplarını serbestzamanlarını değerlendirmeküzere bir araya getirmektedir. Sokak, pasaj, avlu, müze gibi farklı ölçek ve biçimdeki kamusal mekânların birbirine bağlanarak kentliye sunduğu yürüyüş sürekliliği ve bu mekânları deneyimleyen bedenlerin kentsel mekânla kurduğu bağ kentsel kültür dinamiklerinde önemli bir rol oynamaktadır. Açık ve kolay erişilebilir bu kamusal mekânların serbest zaman aktiviteleri bağlamında paylaşıması mimari mekânı toplumsal olarak da inşa etmektedir. Yani Lefebvre'in de ima ettiği üzere, en azından mimar kadar, bu mekânı pratikleyen kentli de onun inşacısı olmaktadır. MuseumsQuartier'ın kentsel sürpriz denilebilecek (tarihi yapılarla çevrili) küçük ölçekli yan avluları bu anlamda kayda değer bir mekânsallığa sahiptir. Ana avluyu iki yönden besleyen yan avlular, çocuklara deneysel bir yaklaşımla odaklanıp gözlem yapma yeteneği kazandıran çocuk müzesi (Zoom Kindermuseum), çağdaş dans santları ve tiyatro 
performans mekânları (Tanzquartier Wien), tütün müzesi (Tabakmuseum), mimarlık kütüphanesi, mimarlık merkezi (Architekturzentrum Wien $-\mathrm{Az}$ W) gibi geniş bir yelpazedeki işlevlere ev sahipliği yapmaktadır (Görsel $13-14)^{11}$.

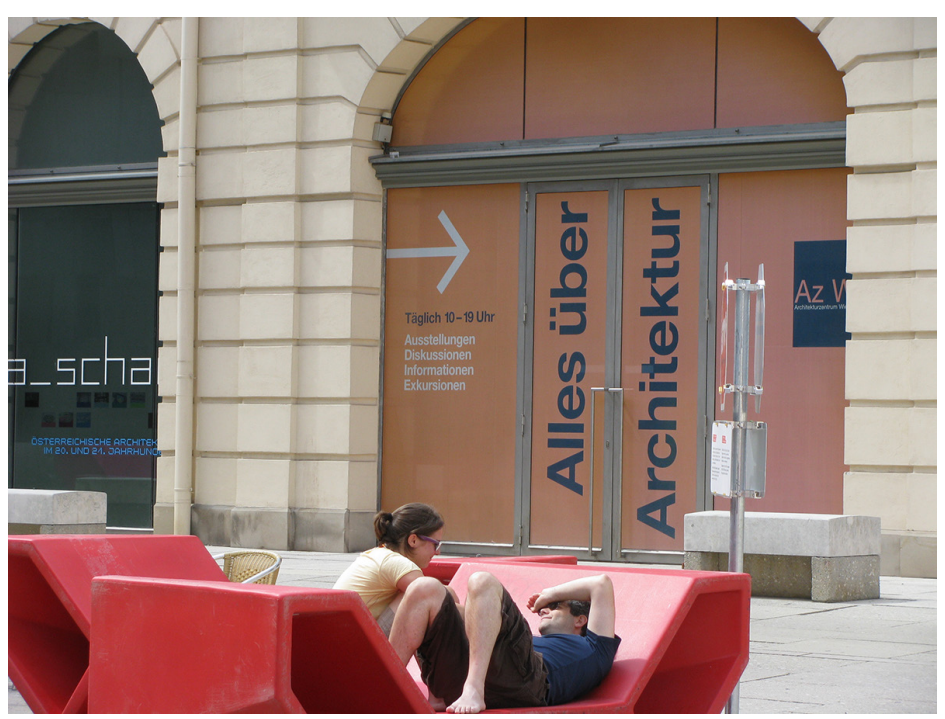

Görsel 13. Mimarlık Merkezi girişindeki yazı: Mimarlık üzerine herşey (Alles über Architektur)

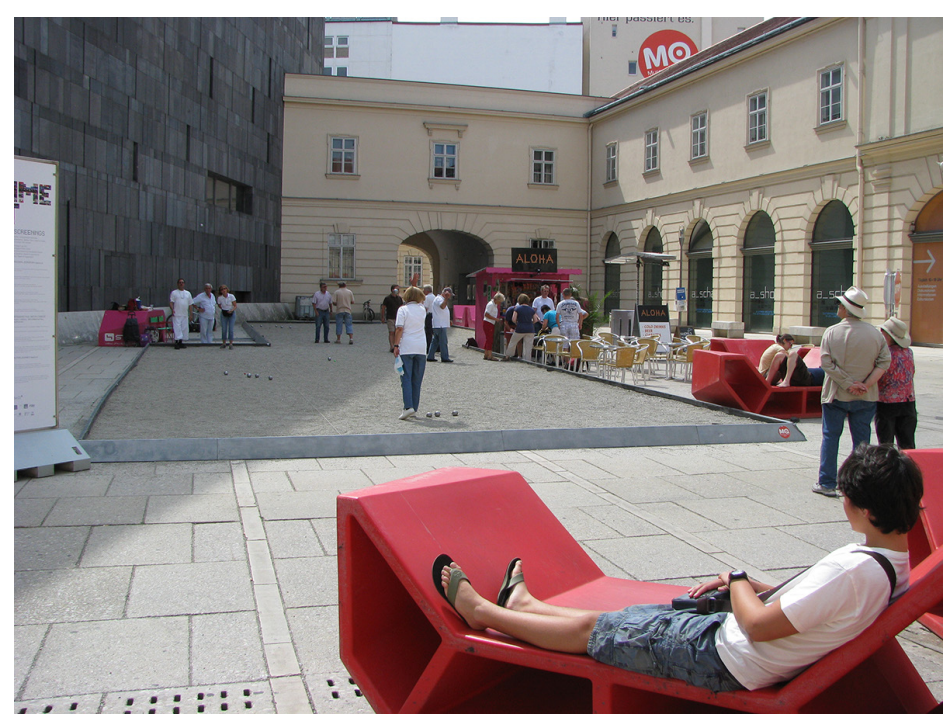

Görsel I4. Mimarlık Merkezine Açılan Yan Avlu

MQ Architektur. (2017). Web: https://www.mqw.at/ueber-uns/architektur/ adresinden I Mart 2017 'de alınmıştı
Kompleksi çevreleyen ve hem ana avlu hem de yan avlulara uzun cepheler veren tarihi yapı grubunun renove edilmesiyle elde edilen mekânlarda sanat-kültür organizasyon merkezleri ve sanatç stüdyolarıbulunmaktadır ${ }^{12}$ Özgün mimari biçimlenmeler aracılığıyla birbiriyle ilişkilenen ve farklı fonksiyonları barındıran yapı gruplarının yanı sıra, modern Leopold Müzesinin üst kattan diğer müzeleri algılamaya olanak sunan tasarımı ile de bu alan kentsel / mimari kurgusu ile yukarıda değinilen "kentin parçası olma" argümanının kapsamlı şekilde mekânsallaşmış halidir (Görsel 1516-17).

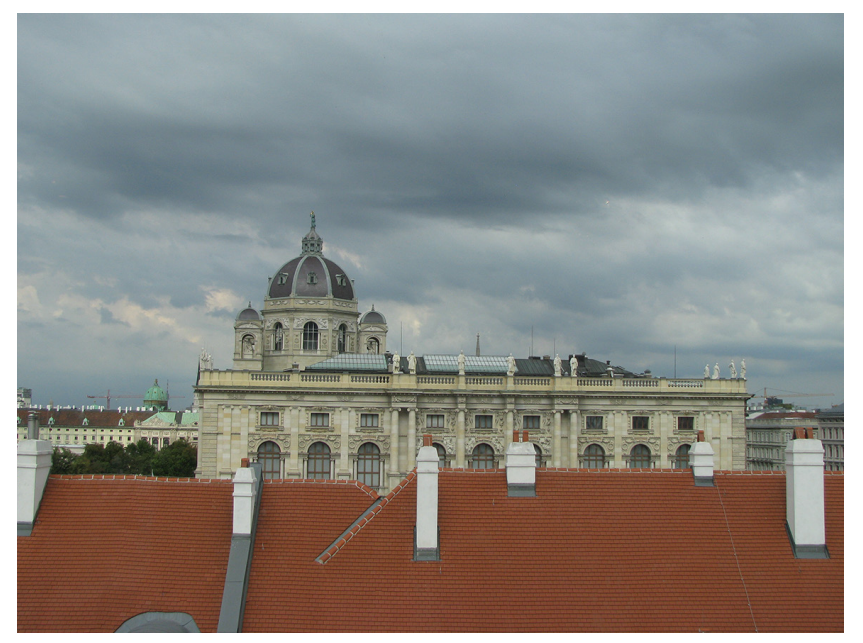

Görsel I5. Leopold Müzesi’nden Çatı ve Gökyüzü

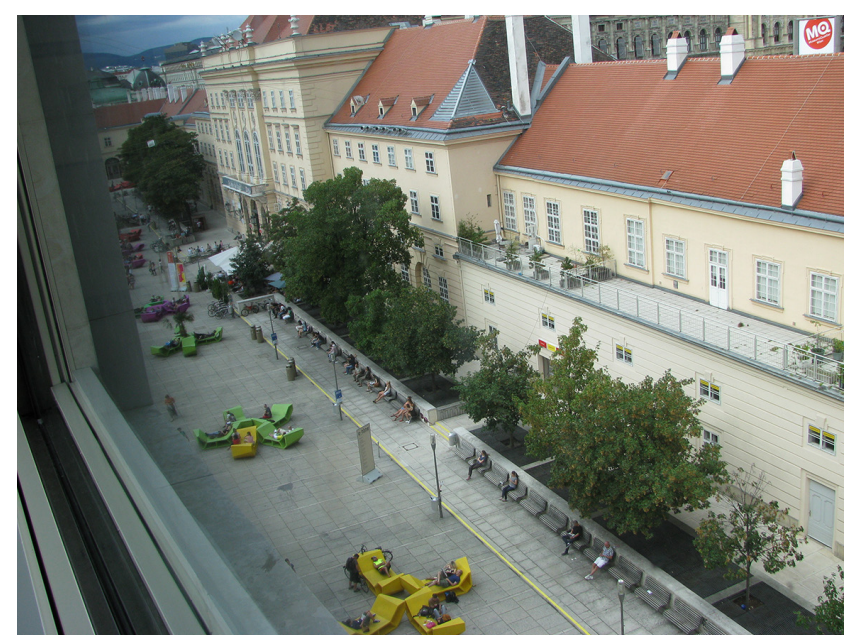

Görsel I6. Leopold Müzesi'nden Avluya ve Eski Ahır Kompleksine Bakış

${ }^{12}$ MQ Courtyards \& Passages. (2017). Web: https://www.mqw.at/en/about/mq-courtyards/ adresinden 7 Mart 2017'de alınmistir. 


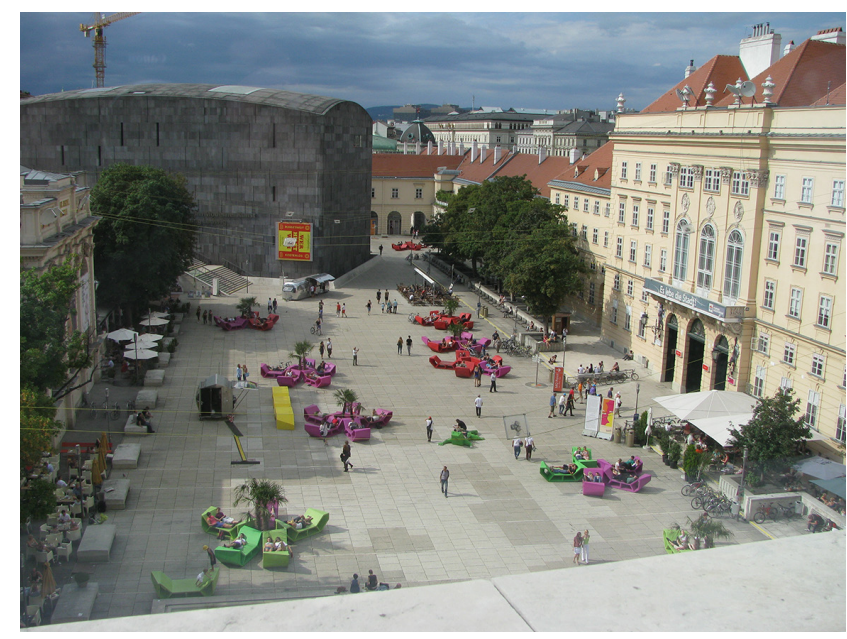

Görsel I7. Leopold Müzesi'nden Avluya Bakış (Solda MUMOK)

Yukarıda değinildiği üzere, burada müze yapılarının temsil ettiği çağdaş mimarlık dili ve yıllar içinde fonksiyonları değişse de 18. yüzyıldan bu yana varlığını sürdüren tarihi doku dramatik bir etki ile buluşmakta; bu buluşma mekâna bir enerji katmaktadır. 18. ve 19. yüzyılda kraliyet at arabalarının, at sulama havuzlarının bulunduğu mekânlarda kentlinin serbest zamanlarını değerlendirmesi ve barok ahır kompleksi içinde MUMOK ve Leopold yapılarının modernist biçimlenmeleri bu enerjiyi gözle görülür kılmaktadır. Ancak, burada vurgulanması gereken önemli bir ayrıntı avlunun sunduğu mekânsal zenginliği arttıran ve yıllar içinde avluyla özdeşleşen kentsel mobilyalardır.

Kentlerin kamusal mekânlarını bütünleyen, kalitesini arttıran ve farklı işlevlerle kentliye kamusal mekânları kullanma olanakları sunan kentse mobilyalar kentteki mekânsal pratiklerin önemli nesnelerindendir. Viyana Müzeler Avlusu'nda da kentlinin avluyu içtenlikle benimseyip onu gündelik yaşamına (özellikle tarihi italyan meydanları için sıklıkla kullanılan metaforla) neredeyse bir 'oturma odası' gibi katışını tümüyle mimari kurguya addetmek ve buradaki kentsel mobilyaların katkısına değinmemek haksızlık olacaktır (Görsel 18). Doğrusu, beden ve kamusal mekân ilişkisini, bu ilişkiyi belirsizlik içinde bırakacak soyut ifadelerle veya mimari temsilin forma dayalı etkin gücüyle aktarmanın ötesine geçmeyi amaçlayan bir yaklaşım için, bu tasarımlar (Enziler) gündelik ve pratik bir gerçeklik sunmaktadırlar. Burada kentsel mobilyalar aracılığıyla güçlenen beden ve mekân ilişkisi bu avluyu ayrıcalıklı kılmakta ve mekânsal pratikler bağlamında, dünyadaki benzer kültürel yapı gruplarının oluşturduğu alanlardan daha farklı bir statüye kavuşturmaktadır.

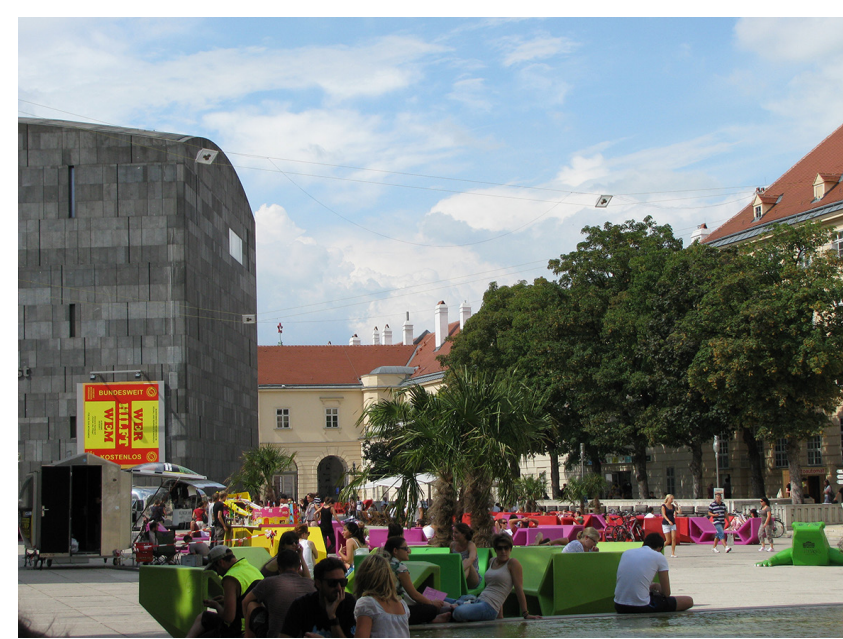

Görsel 18. Avluyu bir 'Oturma Odası' Gibi Kullanan Kentli

2002 yilında MuseumsQuartier (MQ) yönetiminin teklif götürmesiyle Viyanalı mimarlık grubu PPAD (Anna Popelka ve Georg Poduschka) tarafından tasarlanan bu çok amaçı ıent mobilyaları alanın iletişim yöneticisi Daniela Enzi'nin adını almışlardır. MQ avlu mobilyaları, tasarımcılarının yaratıcilığılla ve denemeleriyle pek çok bir araya getirilme versiyonunu mümkün kılan formlarına ulaşmışlardır. Bu versiyonlar kentlilerin Enziler farklı bedensel pozisyonlarla ve pratiklerle kullanmalarına olanak vermektedir. Geometrilerinden kaynaklanan özellikleriyle, sayısız farklı kombinasyonlarla bir araya getirilebilen 150 adet el yapımı Enzi avlunun sembolü olmuş, 2005 yılında Adolf Loos Ulusal Tasarım Ödülü'nü almıştır. 2007 yılından itibaren ziyaretçiler verdikleri oylarla renklere karar vermekte ve Enziler fıstık yeşilinden pembeye, kanarya sarısından kırmızıya her yıl farklı renklere bürünmektedirler. 2010 yılında PPAD'nin MNLS grubuyla ortak tasarladıkları ve fabrikasyon olarak kimyasal mukavemeti yüksek polietilenden ürettikleri yeni Enzo'larla koleksiyon genişlemiştir. Dikey elemanlarla güçendirilmiş iç boşluklu Enzo'lar hem malzemeleriyle hem de strüktürel nitelikleriyle daha dayanıklı tasarımlar olmuştur. 'Eski nesil' Enzilerden ${ }^{13} 64$ tanesi $\mathrm{MQ}$ yönetimince internet üzerinden satışa sunulmuş ve tanesi 600 Avro'dan alıcı bulmuştur (Görsel 19).

${ }^{13}$ Die Geschichte der Enzis. (2017). Web: http://www.enzis. at/en/geschichte/ adresinden 7 Mart 2017 'de alinmistur. 


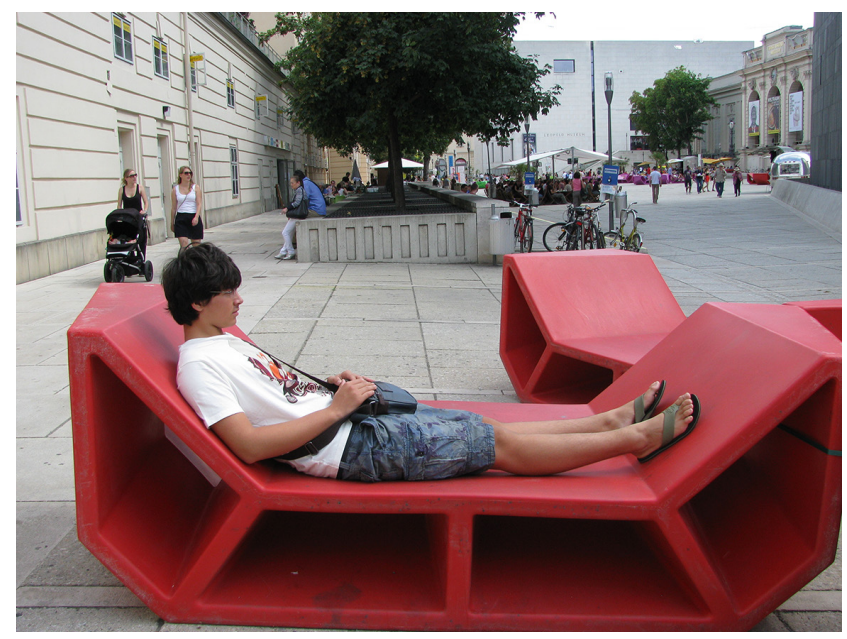

Görsel 19. Yenilenen Strüktürü ve Malzemesi ile MQ Mobilyaları

Avlunun mekânsal pratiğinde önemli bir rolü olan bu değişken kentsel mobilyalar, serbest zamanlarını açık havada ve kentin farklı mimari dokularının buluştuğu bu kültür-sanat alanı MuseumsQuartier'de değerlendirmek isteyen kentliler (ve turistler) için değişik bedensel konforlar sunmaktadırlar (Figür 20).

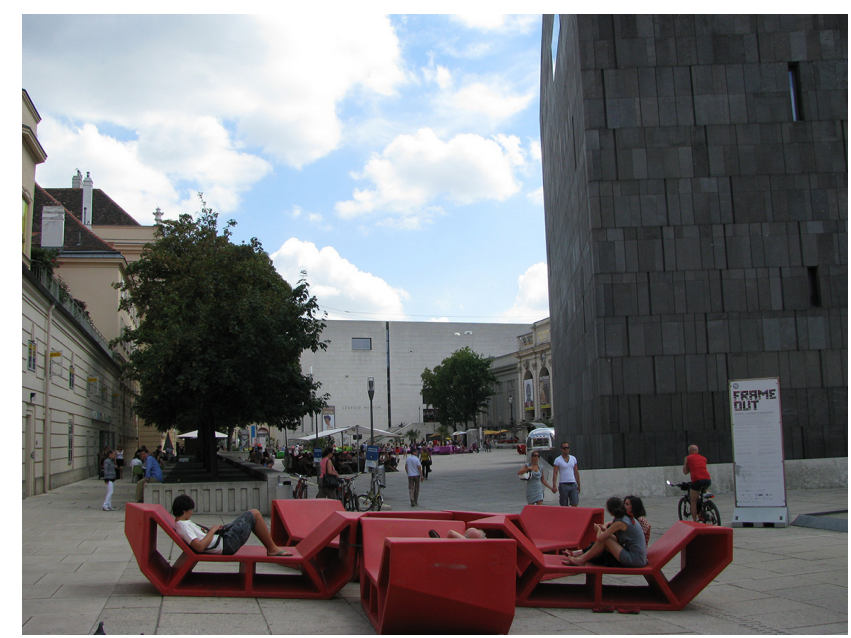

Görsel 19. Yenilenen Strüktürü ve Malzemesi ile MQ Mobilyaları

Büyük kentlerde serbest zamanların ağırlıkı olarak tüketim mekânlarında, yani birbirine benzeyen ve giderek yavanlaşan alışveriş merkezlerinde değerlendirildiği düşünülürse, kentsel kültürün ve sanatın kendine has niteliklerle kesiştiği bu alandaki canlılık ve devinim modern zamanlarda (tüketim dısıı) kamusal mekânların kentin hala güçlü bir bileşeni olabileceği yönünde bir saptamayı desteklemektedir. İşe bu saptamadan yola çıkarak denilebilir ki, Müzeler Avlusu, kamusal mekân ve kamusal bedenin içiçeliğin birbirinin değerini arttıran bir özellikle geliştirmektedir. Bu yazıda serbest zaman bedenleri diye nitelenen özelleşmiş bir kentli tarifi yapılmaktadır. Bu tarif bağlamında avluyu kullananlar, 'mekânı var eden' değilse de, 'mekâna sonradan katılan' da değildir; bu alanı bir kamusal mekân olarak üreten bileşenin 'birbirinden ayrılmaz' parçalarıdır.

\section{Bitirirken: Beden, Mekân, Zaman}

Kentsel mekân olarak avlu, ona anlam veren yapılar ve bu avluyu deneyimleyen bedenler olmadan, sadece soyut bir zemindir. Burada avlu, ifadesini, tarihsel ve çağdaş yapıların birlikteliğinden ve kentsel mobilyaların özgünleştirdiği bir mekân-beden ilişkisinden üretmektedir. Jane Jacobs şehirle uğraşmak hayatın en karmaşık ve yoğun olduğu mekânla uğraşmak demektir der. Hiç şüphesiz bu karmaşık ve yoğun oluşumu çözümlemek belli unsurları öne çıkarmayı gerektirmektedir Bu bakış açısıyla, kentlerin belli parçalarını anlamak için beden, mekân ve zaman üçlemesi önemli bir bileşendir. Bu alandaki beden, mekân ve zaman üçlemesini özel kılan unsurlardan biri ise bu kamusal açık alanın sanatla kurduğu ilişkidir. 'Şehir sanat eseri olamaz' (Jacobs, 1961/2011: 386) ifadesi, kentsel mekânların kendilerinin sanatsal olamayacă̆ın ortaya koyar. Bu vurgunun ima ettiği şey, forma veya içeriğe dair estetik taktiklerle üretilen homojen mekânların hüsran yaratabileceğidir. Ancak, sanatın hayatı anlamlandırmaya ve kavramaya dönük gücü, kendine has kanallarla kentsel kültürün değerlerinden birini oluşurabilir.

Viyana Müzeler Avlusu, sanatla sarmalanmış mekânsallığı ile sanat bireye bu doğal kanallar aracilığılla ulaştıran bir ortam sunmaktadır. Mekânsallığını pitoresk bir mimari kompozisyon olarak değil, sanat ile gündelik yaşam arasında bir arayüz üreterek oluşturmaktadır. Bir sonuçtan çok bir süreç olan böylesi bir mekânsallık sadece bu mekânı pratikleyen bedenlerle kurulan 'anonim bir mutabakatla' (Jacobs, 1961/2011: 387) mümkün olabilmektedir. 'Zaman modernitenin toplumsal mekânında kaybolur' ve 'sadece uzmanlaşmış ölçüm aletlerine (saatlere) kaydolur' diyerek modernitenin mekânsal eleştirisini yapan Lefebvre'e (1974/2014: 120) aksini ispat edercesine, zaman bu avluda mekâna kaydolmakta ve serbest zaman bedenleri aracılığıyla gündelik yaşamda somutlaşmaktadır. 


\section{Kaynakça}

Boeckl, M. (200I). MuseumsQuartier Wien: Die Architektur. New York: Princeton Architectural Press.

Ceballos, S. G. (2004). "The role of the Guggenheim Museum in the development of urban entrepreneurial practices in Bilbao", International Journal of Iberian Studies, I6(3) I, I77186.

Czeike, F. (1994). Historisches Lexikon Wien. Band 3, Wien: Kremayr \& Scheriau.

Francken, D. A. ve Raaij, W., (I98I). "Satisfaction with leisure time activities", Journal of Leisure Research, 13(4), 337-352.

Frantz, M. (2006). "KulturPolitik im Wandel: Hauptstadtsymbolik in Wien und Berlin", ÖZP Austrian Journal of Political Science, 3, 237-253.

Frantz, M. (2005). "From cultural regeneration to discursive governance: Constructing the flagship of the 'Museumsquartier Vienna' as a plural symbol of change", International Journal Urban and Regional Research, 29 (I), 50-66.

Jacobs, J. (20II). Büyük Amerikan Şehirlerinin Ölümü ve Yaşamı (çev. B. Doğan) İstanbul: Metis. (Eserin orjinali I96I'de yayımlandı).

Juniu, S. (2000). "Downshifting: regaining the essence of leisure", Journal of Leisure Research, 32(I), 69-73.

Lefebvre, H. (20/4). Mekânın Üretimi (çev. I. Ergüden). İstanbul: Sel. (Eserin orjinali 1974'de yayımlandı).

Levine, N. (1996). The Architecture of Frank Lloyd Wright. New York: Princeton University Press.

Kurier Zeitung (Kurier Gazetesi). (26.03.2015). “600 Euro für einen alten Enzi”.

Mannel R. C. ve Kleibel, D. A. (1997). A Social Psychology of Leisure. PA State College: Venture.

Manrai, L. A. ve Manrai, A. K. (1995). "Effects of cultural-context, gender, and acculturation on perceptions of work versus social/leisure time usage", Journal of Business Research, 32(2), II5- /28.

Moorhouse, H. F. (1989). Models of work, models of leisure. C. Rojek (Editör) Leisure for Leisure: Critical Essays. London: Palgrave Macmillan, s. 15-35.

Plaza, B. (2000). "Evaluating the Influence of a Large Cultural Artifact in the Attraction of
Tourism", Urban Affairs Review, 36(2), 264-274.

Reicher, C. (2016). Stadtebauliches Entwerfen. Wiesbaden: Springer

Reith, W.J. (1988). "Ein Museuminsel: Architektenwettbewerb Messepalast aufdem Areal der ehemaligen Hofstallungen in Wien, 1988”, Wek, Bauen + Wohnen, 75(5), 10-13.

Rojek, C. (1989). Leisure time and leisure space. C. Rojek (Editör) Leisure for Leisure: Critical Essays. London: Palgrave Macmillan, s. 191-204.

Santagata, W. (2002). "Cultural Districts, Property Rights and Sustainable Economic Growth", International Journal of Urban and Regional Research, 26(I), 9-23.

Scraton, S. ve Watson, B. (2010). "Gendered cities: women and public leisure space in the post-modern city”, Leisure Studies, I7(2), 123-137.

Shaw, S. M. (1985). "Gender and leisure: inequality in the distribution of leisure time", Journal of Leisure Research, I7(4), 266-282.

Tzortzi, K. (2016). Museum as Space: Where Architecture Meets Museology. London and New York: Routledge.

Wehdorn, M. (2004). Vienna: A Guide to the UNESCO World Heritage Sites (çev. P. Lopez). Wien: Springer.

Zacharias, T. (1960). Joseph Emanuel Fischer Von Erlach. Wien: Herold.

\section{Internet Kaynakları}

*MuseumsQuartier Wien'in (www.mqw.at) adresli resmi internet kaynăğyla, alan hakkında çok yönlü ve kapsamlı bilgiye ulaşılabilmektedir. Aşağıda ana menüye bağı dört link yazıya kaynak oluşturmanın yanı sıra okuyucuyu yönlendirmek üzere de verilmektedir.

-Internet: MQ Architektur. (20/7). Web: https://www.mqw.at/ueber-uns/architektur/ adresinden I Mart 20I7'de alınmıştır.

-Internet: MQ Chronik. (2017). Web: https://www.mqw.at/ueber-uns/chronik/ adresinden I Mart 20I7'de alınmıştır.

-Internet: MQ Courtyards \& Passages. (2017). Web: https://www.mqw.at/en/about/mqcourtyards/ adresinden 7 Mart 2017'de alınmıştır.

-Internet: MQ Institutionen. (2017). Web: https://www.mqw.at/institutionen/ adresinden 7 Mart 20 I'de alınmıştır. 
Internet: Die Geschichte der Enzis. (2017). Web: http://www.enzis.at/en/geschichte/ adresinden 7 Mart 2017'de alınmıştır.

Internet: Museumsinsel Berlin-Mitte. (2017). Web: https://www.berlin.de/ museum/3 109074-2926344-museumsinsel-berlinmitte.html adresinden 19 Kasım 2017 'de alınmıştır.

Internet: Museumsstadt Köln (20I7). Web: https://www.koeln.de adresinden 20 Kasım 2017'de alınmıştır.

Internet: Endüstriyel Mirasın Aynası. (2017). http://www.rmkmuseum.org.tr/cengelhan/ turkce/rmk_tarihce.htm adresinden 20 Kasım 20I7'de alınmıştır.

Internet: Erimtan Arkeoloji ve Sanat Müzesi (20I7). Web: http://www.arkitera.com/ proje/4385/erimtan-arkeoloji-ve-sanat-muzesi adresinden 20 Kasım 20I7'de alınmıştır.

\section{Görsel Kaynakları}

Görsel I: Yazar tarafindan çekilen fotoğraf, 2009

Görsel 2: Yazar tarafindan çekilen fotoğraf, 2009

Görsel 3: Yazar tarafindan çekilen fotoğraf, 2009

Görsel 4: Yazar tarafindan çekilen fotoğraf, 201 I

Görsel 5: Yazar tarafindan çekilen fotoğraf, 201I

Görsel 6: https://www.google.com/earth, Google Earth, Viyana, 2017 (2 Mart 2017)

Görsel 7: https://www.google.com/earth, Google Earth, Viyana, 2017 (2 Mart 20I7)

Görsel 8: http://www.habsburger.net/de/medien/johann-andreas-pfeffl-nach-salomonkleiner-das-kaiserliche-hofstallgebaude-kupferstich-I 72434 adresinden 7 Mart 20I 7'de alınmıştır.

Görsel 9: Yazar tarafindan çekilen fotoğraf, 2011

Görsel I0: Yazar tarafindan çekilen fotoğraf, 201I

Görsel II: Yazar tarafindan çekilen fotoğraf, 201 I

Görsel I2: Yazar tarafindan çekilen fotoğraf, 201I

Görsel 13: Yazar tarafindan çekilen fotoğraf, 201।
Görsel 14: Yazar tarafindan çekilen fotoğraf, 201 I

Görsel 15: Yazar tarafindan çekilen fotoğraf, 201।

Görsel I7: Yazar tarafindan çekilen fotoğraf, 201 I

Görsel 18: Yazar tarafindan çekilen fotoğraf, 201I

Görsel 19: Yazar tarafindan çekilen fotoğraf, 20II

Görsel 20: Yazar tarafindan çekilen fotoğraf, 201। 